Revue Française de Civilisation Britannique

\title{
Two Nations Under the Same Roof? Housing and the North-South Divide in the UK
}

Deux nations sous le même toit? Le logement et le fossé Nord-Sud au Royaume-

Uni

\section{David Fée}

\section{OpenEdition} Journals

Édition électronique

URL : http://journals.openedition.org/rfcb/5304

DOI : $10.4000 /$ rfcb.5304

ISSN : 2429-4373

Éditeur

CRECIB - Centre de recherche et d'études en civilisation britannique

\section{Référence électronique}

David Fée, "Two Nations Under the Same Roof? Housing and the North-South Divide in the UK »,

Revue Française de Civilisation Britannique [En ligne], XXV-2 | 2020, mis en ligne le 25 mai 2020, consulté le 27 mai 2020. URL : http://journals.openedition.org/rfcb/5304 ; DOI : https://doi.org/ $10.4000 /$ rfcb.5304

Ce document a été généré automatiquement le 27 mai 2020.

\section{cc)}

Revue française de civilisation britannique est mis à disposition selon les termes de la licence Creative Commons Attribution - Pas d'Utilisation Commerciale - Pas de Modification 4.0 International. 


\section{Two Nations Under the Same Roof? Housing and the North-South Divide in the UK}

Deux nations sous le même toit? Le logement et le fossé Nord-Sud au Royaume-

Uni

David Fée

1 Following 'the severe slowdown in the northern half of the country', it became 'financially safer' for developers 'to build below a line drawn from Cheltenham in the west to Cambridge in the east. ${ }^{1}$

2 The perception of the United Kingdom by its inhabitants has long been influenced by geography. Prior to 1914, British political observers noted a core-periphery cleavage separating the Liberals from the Conservatives, ${ }^{2}$ and in 1930s England, contemporary observers such as George Orwell and J.B. Priestley contrasted a modern South with an industrial North (plus a rural heritage England). ${ }^{3}$ As illustrated by the quote above, this perception of a divided kingdom has given rise in the field of housing to the belief that two nations divided by some invisible line running from the Severn to the Wash are living side by side. To a prosperous booming South is often opposed an ailing North where house prices are increasingly lagging behind.

3 Paradoxically, the North-South divide has been poorly researched by housing specialists. Indeed, housing is usually approached in the UK from a public policy perspective ${ }^{4}$ or an economic one $e^{5}$ but more rarely from a geographical one. ${ }^{6}$ The main publications have rarely focused on the spatial dimension of housing and when they do, they tend to focus on the inner city measures taken from the 1930s onwards (slum clearance), or the place-based programmes designed in the 1960s and revived in the 1990s to tackle spatial inequalities. When they broach the topic of regional variations, they usually focus on differences between the four nations of the $\mathrm{UK}^{7}$ or the consequences of the 1990s reforms of the governance of the $\mathrm{UK}^{8}$ but rarely deal with the sub-regional differences. ${ }^{9}$ 

field of housing (a concept that simply ignores the existence of the Midlands!), not from a public policy perspective but from a housing markets perspective. I shall try to determine whether there is any substance to the slippery concept of a North-South divide in housing, and whether it is still useful to understanding the housing situation in a post-devolution UK. Indeed, it can be argued that this concept reflects popular understandings of the housing market above all but may not really stand up to scrutiny. These beliefs are themselves fueled and shaped by property sections in the media (see the Sunday Times or the Observer for instance) or even monthly house prices bulletins like Savills', Halifax's or Nationwide's that often convey the notion of a binary housing market. ${ }^{10}$

5 Firstly, I shall briefly analyse the official discourse with regard to a North-South divide in housing. Then, I shall examine the issue of the rescaling of housing and the growing importance given to the sub-regional level in England. Then, I shall examine the relevance of the North-South divide in housing in the UK on the basis of four indicators (physical aspect, state of repair, tenure, prices). Thirdly, I shall raise the question of the emergence of new and more relevant housing divides in England. Finally, I shall explore the question of housing policy divergence in a post-devolution UK.

7 I will be using the administrative regions used in 1994 to host the Government offices. Due to the 2014 Secretary of State's decision to end DCLG's provision of regional statistics and the post-2010 abolition of regional governance, it has been difficult to get up-to-date figures and, as a result, statistics often do not cover recent years. It is also difficult to get figures for the whole of the UK as housing is a devolved policy and the Office for National Statistics reports do not always look at the whole of the UK. Another issue is that the four nations use four different methodologies for their four separate surveys of housing: the English authorities conduct a yearly English Housing Survey that focuses on households, physical conditions samples and desk-based market values; the Northern Ireland House Conditions Survey is based on a smaller sample covering the first two items but not on an annual basis; the Scottish House Condition Survey is an annual sample survey on the same items and was merged with the Scottish Household Survey in 2012; the Living in Wales annual sample Survey covered the same items but was replaced in 2009 by the National Survey for Wales. ${ }^{11}$

\section{Housing, the North-South divide and public policy}

Perhaps because the North-South divide is a slippery and contested concept and is politically loaded, too, it has rarely been used by policy-makers in the field of housing. Thus, the 1977 Housing Green Paper that signaled the then Labour government's intention to give more recognition to varying housing circumstances in England and Wales (see below) and move away from national blanket housing programmes, simply underscored the end of a national housing policy and stated: "But the key to the success of national housing policy now lies in the development of effective local housing strategies" ${ }^{12}$.

Likewise, 18 years later, under the Conservatives, the Housing White Paper avoided any references to the concept although it devoted a separate chapter to housing in Wales

Revue Française de Civilisation Britannique, XXV-2 | 2020 
stating "Housing in Wales has some distinctive characteristics which in turn generate particular needs", on the grounds that it had more older and unfit homes. ${ }^{13}$

The New Labour Party's approach to housing policy marked a break as the party came back to power in 1997 with a robust devolution agenda for the UK. Regional governance (see below) was to be at the heart of devolution in England as it would reduce the existing democratic deficit and make local politicians more accountable; it would also make it easier to tailor regional policies addressing regional variations and it would enable collaboration beyond the mere local authority level..$^{14}$ The move towards devolution-based public policy during the New Labour years accounts for the greater prominence given to regional differences in housing official literature in England. Although New Labour never referred to the North-South concept in housing, the 2000 Housing Green Paper, the first one in 23 years, contrasted the housing situation in the North with that in the South, stating: "There are however areas of declining housing demand, particularly in parts of our Northern cities (....) In London and many Southern urban and rural areas, high demand for housing coupled with high house prices has placed acute demand on the social housing stock (...)"15

11 Five years later, this new approach to housing governance in England led to the announcement of a major attempt to rebalance northern and southern housing markets. The government's 2003 housing programme contrasted a greater South East region stretching to Milton Keynes with a North starting around Birmingham. ${ }^{16}$ While the former was allocated "growth areas" to increase housing supply, the latter was imposed areas called "housing market renewal areas" to tackle "housing abandonment" through demolitions and "changes to the housing stock and tenure, in order to encourage income mix and choice". ${ }^{17}$ The publication of the Northern Way in 2004, a growth strategy for the three northern regions spearheaded by John Prescott and mostly devoted to housing, reinforced the feeling that the New Labour government had a binary vision of housing in England ${ }^{18}$ (the Midlands were often referred to although the document was supposed to focus on the three Northern regions only as if the North started at Birmingham in the housing field). Interestingly, the following 2007 Housing Green Paper, published under Tony Blair's successor, Gordon Brown, sought to downplay the divide by announcing growth areas in northern authorities on the basis of deteriorating affordability in the North, although the emphasis was still predominantly on southern housing markets. ${ }^{19}$

12 In 2017, the Conservative Party's Housing White Paper built on the devolution agenda of the Labour years (although the Coalition had previously abolished the regional governance it had inherited), but recast it in localist terms and shied away from drawing a clear North-South dividing line across England's housing markets. Instead, it stated: "At the heart of the White Paper is the acknowledgement that the housing market is very different in different parts of the country". ${ }^{20}$ However, by explicitly referring to the ongoing Northern Powerhouse and Midlands Engine strategies (the latter one being published in March 2017 and a belated recognition that the economy of England did not boil down to a North-South division), the government implied that the housing market in England could be divided into three clear-cut contrasting blocs.

13 As can be seen from the foregoing, although government rhetoric rarely refers to the concept of a North-South divide in housing, the policies formulated at a national level appear to be based on a tacit belief in the divide. This contrasts with the growing 
importance given to local housing markets and the recognition of local, sub-regional differences by policy-makers.

\section{The North-South divide and the rescaling of housing}

14

Since the 1990s, housing policy-making has undergone what some academics have described as a 'rescaling process' ${ }^{21}$ This has helped move away from a simplistic NorthSouth divide or inner cities/rest of the country vision and focus on the boundaries and specificities of individual housing markets. This initially took the form of an increasingly formal government push towards the regional governance of housing, before giving way to a more local approach to housing policy-making. Both stages in this evolution have helped highlight variations in local housing markets and idiosyncrasies within regions.

ater attention by national authorities to local housing situations across the country (apart from inner cities problems) was first given in the late 1970s, as explained above. Whereas national economic inequalities were addressed in the interwar years, the initial signs of the recognition by the public authorities of the spatial dimension of the housing question in the UK only came in 1969 with the Cullingworth Report. The report on Council Housing: Purposes, Procedures and Priorities insisted on the fact that there was not one national housing problem but many different local housing problems that required a reform of the governance of housing and the formulation of local policies. ${ }^{22}$ These recommendations first fed into the work of the Scottish Housing Advisory Committee that examined ways of measuring local housing need and then finally led to a change in the national system in 1977. Local authorities were asked to formulate a Housing plan in Scotland and a Housing Strategy and Investment Programme in England and Wales that would reflect their own housing needs and they would receive a block allocation from the government. Whereas housing programmes and policies used to be centrally driven, they were now to be locally determined and, in theory, centrally funded.

However, gradually, policy-making in the field of housing came to be seen as too local, narrowly focused and parochial. As a consequence, a regional governance of housing emerged in the early 1990s when the then Department for the Environment published a document demanding that each administrative region should have an up-to-date regional guidance covering issues of regional importance, including "the scale and distribution of provision for new housing". ${ }^{23}$ Once issued by the Secretary of State, local authorities were required to have regard to it when preparing their plans. In 1994, the creation of nine Government offices for the Regions tasked with delivering government policy at a sub-national level, managing spending programmes and linking departmental policies across boundaries further institutionalized the evolution of policy-making in housing. ${ }^{24}$

The New Labour government came to power on a greater regional ownership and devolution agenda in 1997 and altered the system along the lines announced in a DETR 1998 publication. ${ }^{25}$ As a result, in 1999 the New Labour government created indirectly elected Regional Assemblies that became responsible for producing a statutory Regional Spatial Strategy (covering a number of related issues including assessment of new housing requirements and land availability) after the passing of the Planning and Compulsory Act 2004. As of 2003, in order to address the question of household growth,

Revue Française de Civilisation Britannique, XXV-2 | 2020 
and following the rediscovery of the issue of housing supply, ${ }^{26}$ each region was to have a Regional Housing Board in charge of formulating a Regional Housing Strategy reflecting the housing priorities of the region. All planning authorities (at the local and regional level) were strongly encouraged to conduct local housing market assessments in order "to inform the development of spatial housing strategies". ${ }^{27}$

Further developments reinforced the rescaling of housing policy-making to a regional level and underscored the importance of regional housing markets and their differences. In 2006, the then Labour government altered the philosophy and operation of the planning system fundamentally following the Barker Review and the 2004 final report (recommendation 5). A new body -the National Housing and Planning Advice Unit- was set up and charged with setting national and regional affordability targets that Regional Planning Bodies (ie the Regional Assemblies) were to achieve by determining the "numerical trajectories for new housing supply". ${ }^{28}$ Affordability targets were calculated in terms of the ratio of lower quartile house prices to earnings and house prices became the key drivers of the regional planning bodies' housing policies.

Following a number of publications ${ }^{29}$ the Labour government became increasingly nervous about the potential misfit between economic performance and housing markets. Housing policies became framed in a broader competitiveness agenda. ${ }^{30}$ After the 2007 Sub-national Review, this led to a number of reforms designed to integrate housing and economic policies into single regional strategies. Above all, it led to a strong drive on the part of the government to make sure local authorities collaborated at a sub-regional level, ideally at city-region level: new guidelines were published on how to identify sub-regional housing market areas ${ }^{31}$ or to form Multi-Areas Agreements between local authorities ${ }^{32}$, and late, in 2007, 13 sub-regions working towards a MAA were announced.

Although the whole of the regional governance in England was dismantled by the incoming Coalition Government after 2010, this sub-regional approach was retained. Local Authorities were left to their own devices again, in the name of localism, and given the freedom to determine their own housing needs. However, they were submitted to a duty to cooperate enshrined in the Localism Act 2011 when preparing their local plan on cross boundaries strategic priorities and to demonstrate they have complied with the duty. Likewise, a requirement to prepare a Strategic Housing Market Assessment and to assess local housing needs in conjunction with neighbouring authorities when housing markets cross local boundaries was set out in the 2012 National Planning Policy Framework ${ }^{33}$ and the Planning Practice Guidance 2014 (Duty to cooperate).

21 Finally, following the Cities and Local Government Devolution Act 2016, recent devolution developments under the Conservative government seem to strengthen the initial city-region agenda of their predecessors and appear as a return to strategic planning at a sub-national level. In May 2017, powers, budgets and responsibilities were transferred from Westminster to new combined authority mayors in 6 regions across England (Greater Manchester, Cambridge and Peterborough, Liverpool City Region, Tees Valley, West Midlands and West of England). In Manchester, this new stage in the devolution agenda initiated in 1997 by Labour will make the new Mayor responsible for preparing a spatial development strategy that will show how he intends to meet local housing needs in order to support the local economy. ${ }^{34}$ 
All these developments have reinforced the growing interest for local housing markets that has been building since the late 1970s as well as the degree of sophistication of housing analysis at the expense of a simplistic North-South perspective. Defined in some government documents as "geographical areas defined by household demand and preference for housing on the basis of house prices, household migration and search patterns as well as contextual data", ${ }^{35}$ housing market areas (whether local or sub-regional) are seen today as the most appropriate spatial level for housing analysis and increasingly for policy-making, too.

Having explored government discourse and policy-making with regard to the NorthSouth divide in the field of housing, we shall now look at four different indicators (type of homes, state of repair, tenure, prices) that together further show that the concept needs qualifying.

\section{A North-South divide in UK housing?}

\section{Types of homes}

24 We should start by examining something that may seem trivial but that does undermine popular beliefs, namely the built environment. Indeed, it is often assumed that, due to its strong industrial past, northern England is a land of back to backs, two up two down homes while the south England is a land of pleasant suburban homes. On the basis of statistics, how do regional housing stocks compare?

The Land Registry data for England and Wales ${ }^{36}$ provide some elements of answers about the type of property sold and so an insight into the physical aspect of the built environment since homeownership is dominant in the UK. ${ }^{37}$ They show that there is no clear North-South divide but rather multiple divides along industrial versus non industrial settlements lines, interwar semis versus post-1945 detached lines or urban renaissance inner city versus suburban homes lines. At a UK level, the four nations share similar features but display well-known differences, too: semi-detached homes and detached homes, often the legacy of the interwar private housing building boom, are the most prevalent types of dwellings in the UK (44.3\% in England, 39.3\% in Northern Ireland and $48 \%$ in Wales) except in Scotland where flats (whether high or low rises) account for $36 \%$ of all dwellings, far ahead of England (17.9\%). Terraces, the legacy of the industrial era, are the second most frequent type of dwellings in all nations (between 28 and 31\%) except in Scotland where the percentage is lower (20\%). Northern Ireland has twice the proportion of bungalows (21\%) as the other nations. ${ }^{38}$

\section{The state of repair}

Contrary to expectations, there is no perfect North-South divide either when it comes to the state of repair of regional housing stocks. British people in the North are not necessarily more poorly housed. In July 2011, the region with the highest rate of nondecent homes was the South West with close to $40 \%$ of the stock, whereas the region with the lowest was the North East with less than $25 \%{ }^{39}$ London stood in the middle and the Midlands were divided between East and West, with a higher proportion in the latter. Interestingly, the few reports and statistics there are on the sub-national situation show that there is no clear link between poverty and non-decent living 
conditions. This disconnection is due to the major renovation programmes that took place in the late 1990s and 2000s (the Decent Homes programme) at the behest of the central Labour government after Public Sector Agreements were defined and targets set. ${ }^{40}$ These have had a massive impact ${ }^{41}$ on the state of social housing (much present in inner cities and in the North in particular) and have reinforced the gap with a poorly regulated and little renovated private rented sector often more frequent in the South.

At the UK level, statistics show significant differences between the four nations again: dwellings displayed a low incidence of damp in Northern Ireland (4.1\%) compared to Wales and Scotland (over 12\%) with England in the middle (7.6\%). ${ }^{42}$ Since the four nations define poor housing on a different basis (England and Wales use the Decent Homes Standard, Scotland the Tolerable Standard and Northern Ireland the Fitness for Habitation Standard) comparisons are difficult in this area, too, and surveys have often used the Housing Health and Safety Rating system instead. This is used in the UK (except in Scotland) to identify and assess problems in dwellings and rank them on the basis of their severity (minor to potential lethal). Welsh dwellings come out worse when it comes to category 1 hazard (28.7\% of them) against $22.2 \%$ for England and $18.3 \%$ for Northern Ireland, as well as excessive cold. ${ }^{43}$

\section{Tenure}

Seen from a tenure perspective, the sub-regional picture of housing is equally surprising and challenges the concept of a North-South divide. In 2011, rates of home ownership varied across England between $62 \%$ and $70 \%$, with two Northern regions (North East and Yorkshire and the Humber) below the national average of $64 \%$ but not much. ${ }^{44}$ The three regions with the highest percentages were in the South, but London stood out as the one region at odds with all the others. Despite decades of national policies in favour of home ownership, the home ownership rate of the capital remained far below the national average at $50 \%$, reflecting the soaring house price of the capital (see below). Rates in the private rented sector were even more similar with a $3 \%$ difference only between the regions with the lowest percentage (North East and West Midlands at 15\%) and the one with the highest (Yorkshire and the Humber at 18\%). Once more, the main divide was between London (26\%) and the rest of the country, reflecting the greater financialisation of housing in the capital and investment in buyto-let programmes. The clearest divide indication of a North-South divide could be seen in the social housing sector where there was a $10 \%$ gap between the percentage of social dwellings in the North East (23\%) and the South East (13\%), reflecting the widely different outcomes of the Right-to-Buy policies since 1980. Again, London had a profile much closer to that of the Northern regions with a $24 \%$ percentage.

At UK level, the four nations display marked differences in tenures: although homeownership is predominant in each of them, statistics show variations from $63 \%$ in Scotland to $73 \%$ in Wales. The private sector that has experienced a revival in the UK since the 1980s, is far more present in Northern Ireland (17.9\%) than in the other nations, with Scotland and Wales showing an equally low percentage (around $9 \%$ of all dwellings). Finally, the social sector occupies a similar place in England, Wales and Northern Ireland (between 15 and 17\%) but with important differences in the balance between local authorities and housing associations, and still represents a much higher percentage in Scotland (27.5\%). ${ }^{45}$ 


\section{House prices} and have helped give credence to the concept of a North-South divide in housing, running across the middle of the UK. The UK media's obsession with housing is fuelled by ever wider regional variations and a growing North-South divide in house prices that is three times higher than in $2005 .{ }^{46}$ House prices, unlike the previously mentioned indicators, are strongly influenced by the economic geography of the country. Between 2015 and 2016, the closer a house was from London, the steeper the price increase: while prices had increased by $11.5 \%$ in London and $8.3 \%$ in the South East, they "only" went up by $5.8 \%$ in East of England and the South West, 4.1\% in the West Midlands, 1.7\% in Wales, $0.5 \%$ in the North West and even declined by $0.2 \%$ in Scotland and $1.1 \%$ in the North East ${ }^{47}$.

Furthermore, since the 2008 recession, regional markets have displayed wide differences in terms of recovery. While all southern regions enjoyed in 2014 higher house prices than their pre-crisis index peaks (ranging from $+12.9 \%$ for the South East to $+2.2 \%$ in the South West), the Midlands and Scotland had just recovered from the recession (from $+1.1 \%$ in the West Midlands to $+0.7 \%$ in Scotland) and northern and Welsh prices remained below (between $-0.8 \%$ in Wales and a hefty $-46.7 \%$ in Northern Ireland). ${ }^{48}$ Over a 20 year period (1995-2015), most towns and cities in the North and Midlands of England saw a price increase between $150 \%$ and $250 \%$, against $250 \%$ to $350 \%$ in the South. ${ }^{49}$ These differences can be accounted for by different regional inward investment, jobs growth and employment rates as well as migration levels and housing shortages.

At city level, a study of house prices in towns and cities in England and Wales on the basis of house prices statistics for small areas (HPSSAS) confirms a broad North-South divide..$^{50}$ In the South, 29 out of 45 towns and cities above 75,000 inhabitants had a median house price above $£ 200,000$ in 2015 but only 3 out 64 cities in the North and Midlands did. In the South, between 2010 and 2015, 26 out of 45 towns and cities had experienced median house price growth of over $20 \%$ or so, while nine out of 64 had in the North and the Midlands. ${ }^{51}$

The growing regional gap in house prices along a North-South line is not new and was first diagnosed in the 1960s when it started opening. It is sometimes said to be part of a cycle that evens out differences over the long term..$^{52}$ According to those researchers, during periods of growth, there is great diversity between regions but in recession, these differences reduce and over the long term (1973-1998) there was similar overall growth across the country. As a result, no North-South divide, as measured according to this analysis, could be highlighted before 1998. However, in a context of growing financialisation in southern markets, it remains to be seen whether these past trends will be repeated and whether over the long term the current North-South divide in house prices will even out.

So although the expression 'North-South divide' rightly illustrates the growing differences in house prices across the UK, it fails to reflect the state and profile of the national housing stock accurately. It is also too simplistic when studying today's housing markets.

Revue Française de Civilisation Britannique, XXV-2 | 2020 


\section{New geographies of housing inequalities?} national level as well as an increasingly complex picture at the level below the regional. London increasingly stands out from the rest of the country and local variations have become wider.

\section{The new divide: London strikes out}

The London housing market has indeed become unlike any other in the country. In the past, London house prices moved ahead of the rest of the country at the beginning of an upturn in house market cycles ${ }^{53}$ but this is no longer the case, it seems (although a new trend may be emerging, see conclusion). Although there has been no national upturn in the housing market since the recession of 2008, London has already fully recovered. By 2015, property prices in the capital were 10\% above their 2007 peak while nationally they were still $6 \%$ below. House prices had increased by $49 \%$ there since the 2009 trough compared to $19 \%$ nationally and the average London house price was $90 \%$ above the UK average..$^{54}$ In the private rented sector, rents are also far higher: the median monthly rent was $£ 1,300$ in the capital in 2014 against $£ 595$ in the UK. ${ }^{55}$ As a result, affordability ${ }^{56}$ has declined much faster in the capital than in the rest of the country: in 2014, private sector tenants in London spent $36 \%$ of their gross income on housing costs, ${ }^{57}$ and as a whole, between 2008 and 2014, Londoners' disposable income after housing costs fell by $4 \%$ and that of private renters by $28 \%$ between 2001 and 2011 . ${ }^{58}$ Another indication of the unique trajectory of the capital is that while in 1999 five out of the ten least affordable local authorities in England and Wales were in London, there were seven out of ten-in 2016. ${ }^{59}$ Although the South East housing market displays similar features and is fuelled by Londoners relocating in the region, it remains significantly cheaper. By 2014, house prices had risen fastest than in any other region but significantly more slowly than in London $(+12.9 \%$ and $+39.7 \%$ respectively $) .{ }^{60}$ In September 2017, average house prices stood at $£ 484,000$ in London but $£ 324,000$ in the South East, higher than in any other region. ${ }^{61}$

The capital also stands apart from other regions for its unique tenure system: in 2014-15, owner occupiers represented only 50\% of all households (against 66\% nationally), whereas $27 \%$ of them were in the private rented sector (up from $15 \%$ in 1996) against $18 \%$ nationally. ${ }^{62}$ Furthermore, $23 \%$ of households were in social housing, well above the national percentage of $16 \%$. Outright home ownership is lowest in the capital at $23 \%$ compared to $33 \%$ of all households in England. ${ }^{63}$ However, the tenure system in the capital is uneven, with a marked divide between inner and outer London: while in the former the home ownership rate was $36 \%$ in 2016, in outer London it was $58 \% .^{64}$

These unique features can be accounted for by the extreme financialisation of the London property market (visible in the amount of foreign investment and the development of Buy-To-Let programmes that amount to $24 \%$ of the English total) ${ }^{65}$ its rapid demographic growth (double the rate of the UK, at 14\% between 2004 and 2014) (66 $^{6}$ and, as a result, the short-fall of homes and declining affordability (see above). To these must be added the widening economic gap with rest of the country, the London economy outperforming all other UK regions and growing by $20 \%$ between 2009 and

Revue Française de Civilisation Britannique, XXV-2 | 2020 
2013 compared with the UK at $13.9 \% .{ }^{67}$ Despite the 2008 recession, total employment today is higher than before the 2008 peak and 0.7 million jobs were created between 2009 and $2014 .^{68}$

However, beyond the growing divide between the capital and the rest of the country, there are signs that the national housing market picture has become increasingly complex and fragmented. In a country where home ownership is the be all and end all of housing policy, other crises appear to be in the making in parts of northern England, traditionally thought to be unaffected by the housing affordability crisis.

First, it should be noted that regional averages for the Midlands and the North conceal pockets of wealth and areas of high house prices: for instance, in 2015, Harrogate, Solihull and Sutton Coldfield had median house prices above $£ 200,000$, higher than many cities and towns in the South. ${ }^{69}$ Besides, variations are almost as wide within regions as between regions: in 2015 median house prices in the North and Midlands reached $£ 237,000$ in Sutton Coldfield but only $£ 78,000$ in Burnley. In the South, median house prices in Peterborough were only $£ 148,000$ but $£ 390,000$ in St Albans. ${ }^{70}$

41 Another telling sign is that some Northern cities (similar to housing bubbles in their region) saw a rapid rise in house prices when the economy started recovering. One of them was Durham, which was the town with the seventh biggest rise in average house prices in 2011-12 (12.6\%) just below six southern towns and cities. ${ }^{71} \mathrm{~A}$ more worrying sign is that many northern cities have experienced a double digit fall in home ownership rates, similar to that of outer London and well above the national average of 7\% since the peak of home ownership in 2003. The sharpest decrease in England is found in Manchester: while $72 \%$ of households were homeowners in 2003, there were $58 \%$ in 2015. Double digits falls have also occurred over the same period in the West Midlands (-11.2\%), South Yorkshire (-9.8\%) and West Yorkshire (-10.6\%) metropolitan areas and all core northern cities except Tyne and Wear and Merseyside. ${ }^{72}$

42 Finally, the annual rate of house price inflation in some northern core cities appears to be accelerating: the year-on-year growth rate in Manchester reached $8.4 \%$ between July 2015 and July 2016, very similar to that of London the previous year. House price inflation was not far behind at $7.6 \%$ in Birmingham and $7.7 \%$ in Liverpool, outstripping southern cities like Bournemouth $(+6.6 \%) .^{73}$

Manchester is a case in point. Indeed, the local context displays similar features to the London one. The city is suffering from a growing shortfall of 10,000 homes although it has attracted thousands of Buy to Let schemes for the last two decades that have transformed the face of the city centre. The short-fall is partly due to the fact that Manchester has gained thousands of international migrants between 2007 and 2012 $(36,000)$ who have fuelled the city's net demographic gain $(20,000)$. It is also due to the rapid growth in the number of professional jobs in the past decade $(+50 \%)^{74}$ that have caused the city centre's population to triple between 2001 and 2011. ${ }^{75}$

As can be seen, housing market trends in some northern core cities are increasingly at odds with the rest of their surrounding region and have more in common with those in the South of the country. They invalidate the notion of a simple North-South divide in housing. What is more, the national picture has been made more complicated by the New Labour national devolution agenda implemented since 1997. 


\section{The North South divide in post-devolution UK} referendum on further devolution. They have increasingly diverged since then. In 2014, the Housing Wales Act placed a stronger duty on local authorities to prevent homelessness and non-priority households were brought within the remit of rehousing duties. ${ }^{83}$ After restricting the Right to Buy in 2015, the Welsh administration introduced a bill to abolish it in March 2017. Just like in Scotland, the private rented sector has become more tightly regulated than in England following compulsory registration under the Housing Wales Act 2014 and long-term empty homes have been taxed twice more. ${ }^{84}$

49 Finally, in Northern Ireland, "policy has tended to reflect English policy...power sharing has tended to produce the "lowest common denominator" 85 and as a result some policies-such as stock transfer-have been shelved.

50 Although their scope is limited by money transfers from Westminster, devolved governments can make policies that impact the financialisation of local housing and its 
production. As a result, it is likely that the distribution of housing tenures will increasingly diverge from that in England in the future. These variations could in turn have an effect on the evolution of sub-national and regional house prices. For instance, the Scottish Government announced in 2011 that it aimed to provide an affordable home for all by 2020. To do so, it is looking at new ways of financing housebuilding and aimed to provide 18,000 new affordable homes by $2014 .{ }^{86}$ Likewise, the Welsh Government is committed to building 20,000 affordable homes and supporting housing associations to build more homes. ${ }^{87}$ Different housing policies from England's and a greater supply of affordable homes are likely to have an impact on house prices in those two nations.

\section{Conclusion}

51 In the field of housing, paraphrasing the Hills report on inequalities, one could say that "looking across the English regions does not suggest a simple 'North-South divide' ... but there are often differences between London and the South East and other regions" 88 and even more so between London and the rest of the country. London's housing market and system (and to some extent the South East's) are becoming so unlike the rest of the country that it would be better to speak of the London (South East)-UK divide.

The national picture is further complicated by the fact that looking at housing markets at the regional level is not enough. Regional differences in housing markets conceal and play down variations within regions between local authorities or cities and their surrounding region. This sub-regional level is often more useful to understanding variations across the country.

Differences in regional housing markets matter: since housing is the most widely distributed form of wealth in the UK population, it has the biggest impact on wealth inequalities in the UK. This means that aside from having an impact on living conditions housing also accounts for a predominant part of wealth inequalities between regions. This explains why in 2010 the Hills committee noted that: "Median total household wealth is $£ 288,000$ in the South East, 1.7 times that in the North West. Wealth inequality is very high in all regions, but especially in London, with a tenth of households with little or no wealth, and a tenth having more than $£ 934,000 " .{ }^{89}$ However, between January 2017 and January 2018, London and the South East experienced some of the lowest annual rises in house prices, well below other regions. ${ }^{90} \mathrm{As}$ for it, the Royal Institute of Chartered Surveyors is predicting a fall in 2018 in these two regions, ${ }^{91}$ raising the prospect of a possible return to a former housing prices pattern (see section on London).

Beyond the geographical divide, a growing divide is to be found in the growing generational gap, too. As a result of rising house prices, following the Great Recession of 2008 and the withdrawal of many loans and the need to have a higher deposit, the percentage of young people between 25 and 34 who are private rented sector tenants has gone from $24 \%$ in 2004-5 to $46 \%$ in 2014-15. ${ }^{92}$ The rise of a 'Generation Rent' will undoubtedly have major consequences on inter-generational wealth distribution and will reinforce geographical differences in housing. 


\section{BIBLIOGRAPHIE}

BALCHIN Paul, Housing Policy, An Introduction (London, Routledge, 1995).

BARNES Yolande, "Population Change:-the Market Impacts", pp. 35-40 in BATE R., BEST R. and Holmans A. (ed.), On the Move: The Housing Consequences of Migration (York, Joseph Rowntree Foundation, 2000).

BRAMLEY, Glen, “The Sudden Rediscovery of Housing Supply as a Key Policy Challenge”, Housing Studies 22: 2 (2006), pp. 221-241.

BRAMLEY, Glen, “Meeting Demand”, pp. 161-183 in MALPASS Peter and RoWLANDS Rob, Housing Markets and Policy (Abingdon, Routledge, 2010).

DEPARTMENT FOR COMMUNITIES AND LOCAL GOVERNMENT, Homes for the Future: More Affordable, More Sustainable (London, The Stationery Office, 2007).

DCLG, Strategic Housing Market Assessment, Practice Guidance, Planning (London, The Stationery Office, 2007).

DCLG, Identifying Sub-regional Housing Market Areas (London, DCLG, 2007).

DCLG, Taking Forward the Review of Sub-national Economic Development and Regeneration (London, DCLG, 2007).

DCLG, National Planning Policy Framework (London, DCLG, 2012).

DCLG, English Housing Survey, Headline Report 2014-15 (London, ONS, 2016).

DCLG, Fixing our broken Housing Market, Cm 9352 (London, DCLG, 2017).

DCLG, Devolution: A Mayor for Greater Manchester (London, DCLG, 2017).

DEPARTMENT OF THE ENVIRONMENT, Housing Policy: A Consultative document (London, The Stationery Office, 1977).

DOE, Planning Policy Guidance 12: Development Plans and Regional Planning Guidance (London, HMSO, 1992).

DOE, Our Future Homes, Opportunities, Choice, Responsibility (London, HMSO, 1995).

DEPARTMENT OF TRADE AND REGIONS, The Future of Regional Planning Guidance (London, The Stationery Office, 1998).

DETR, Quality and Choice: A Decent Home for all (London, DETR, 2000).

ECONOMIST (THE), “Living in London: the grip tightens", 30 $0^{\text {th }}$ April 2016.

ECONOMIST (THE), "Housing in British Cities: Little Londons", 24 $4^{\text {th }}$ September 2016.

ELLIOTT Larry, "House Prices to fall in London and South East, say Surveyors", The Guardian, 20 December 2017.

FIELD William, Regional Dynamics: The Basis of Electoral Support in Britain (London, Franck Cass Publishers, 1997).

FORREST Ray and MING YIP, Ngai. Housing Markets and the Global Financial Crisis (Cheltenham, Edward Elgar, 2011). 
HALIFAX, London thrives-widening the divide between the capital and the rest of the country, press release, 15/01/2015.Retrieved from https://static.halifax.co.uk/assets/pdf/mortgages/pdf/ London-thrives-widening-the-divide-between-the-capital-and-the-rest-of-the-country-15thJanuary-2015-Housing-Release.pdf

HILLS John et al., An Anatomy of Economic Inequality in the UK: Report of the National Equality Panel (London, Government Equalities Office, 2010).

HOLMANS Alan, Past and Current trends in House Prices and Incomes and Access to Home Ownership (Cambridge, Cambridge UP, 2001).

HOMETRACK, UK CITIES House Price Index released, July 2016, Retrieved https://www.hometrack.com/ uk/insight/uk-cities-house-price-index/july-2016-cities-index

LEE Peter, “Competitiveness and social exclusion”, pp. 184-202 in MALPASS Peter and ROWLANDS Rob, Housing, Markets and Policy (Abingdon, Routledge, 2010).

LLOYD Tom, "Figures reveal scale of regional house price divide", Inside Housing, 2 January 2016.

LUND Brian, Housing Politics in the UK: Power, Planning and Protest (Bristol, Policy Press, 2016).

LYNCH Russell, "North-South divide in house prices is highest ever", The Independent, 30 December 2015, Retrieved from http://www.independent.co.uk/news/business/north-south-divide-inhouse-prices-is-highest-ever-a6791326.html MALPASS Peter and MURIE Alan, Housing Policy and Practice (Basingstoke, Routledge, 1999).

MALPASS Peter and RoWLANDS Rob, Housing, Markets and Policy (Abingdon, Routledge, 2010).

MAYOR OF LONDON, Homes for London, the Mayor's Housing Strategy (London, GLA, 2014).

MAYOR OF LONDON, Equal Life Chances for All (London, GLA, 2014).

MILIGAN BRIAN, “North-South House Price Divide Hits Record High”, BBCNews, 1 April 2016

Retrieved from www.bbc.com/news/business-35941503

MULLINS David and MURIE Alan, Housing Policy in the UK (Basingstoke, Palgrave, 2006).

NATIONWIDE, Price Index Press Release, March 2018, Retrieved on 2 April 2018 from https:// www.nationwide.co.uk/-/media/MainSite/documents/about/house-price-index/2018/ Mar_Q1_2018.pdf.

o'sullivan Tony and GIBB Kenneth, Housing Economics and Public Policy (Oxford, Blackwell, 2003).

OFFICE OF DEPUTY PRIME MINISTER, Your Region, Your Choice (London, HMSO, 2002).

ODPM, Sustainable Communities: Building the Future (London, ODPM, 2003).

ODPM, Making it Happen: The Northern Way (London, ODPM, 2004).

ODPM, Competitive European Cities: where do the Core Cities Stand? (London, ODPM, 2004).

OFFICE FOR NATIONAL STATISTICS, Table 109, Dwelling Stock by Tenure and Region from 1991, 2014, Retrieved from www.gov.uk/government/statistical-data-sets/live-tables-on-dwelling-stockincluding-vacants.

ONS, Trends in the United Kingdom Housing Market (London, ONS, 2014).

ONS, House Price Statistics for small areas: year ending December 1995 to year ending March 2016

(London, ONS, 2016).

ONS, Towns and Cities Analysis, England and Wales, London (ONS, March 2016). 
ONS, Overview of the UK population (London, ONS, 2016).

ONS, Housing Affordability in England and Wales: 1997 to 2016 (London, ONS, 2017).

ONS, UK House Prices Index: September 2017 (London, ONS, 2017).

OXLEY Michael, “Economics”, Planning and Housing (Basingstoke, Palgrave, 2004).

PIDDINGTON Justine, GARRETT Helen and NOWAK Tad, Housing in the UK: national comparisons in typology, condition and costs of poor housing (Watford, HIS BRE press, 2013).

POVERTY SITE (THE), Poverty indicators: Non-decent homes, by region, Retrieved on September $13^{\text {th }} 2016$, on www.poverty.org.uk/78/index.shtml.

RESOLUTION FOUNDATION, Home Ownership struggle hits Coronation Street, 2 August 2016, Retrieved from http://www.resolutionfoundation.org/media/press-releases/home-ownership-strugglehits-coronation-street

SAVILLS RESEARCH, Spotlight: Prime Residential Markets beyond London, 2015, Retrieved on 2 April 2018 from http://www.savills.co.uk/research_articles/186866/187207-0.

scoTT Peter, Triumph of the South: A Regional Economic History of Early Twentieth Century Britain (Aldershot, Ashgate, 2007).

SCOTTISH GOVERNMENT, Homes Fit for the $21^{\text {st }}$ Century, The Scottish Government Strategy and Action Plan for Housing in the Next Decade, 2011-2020 (Edinburgh, Scottish Government, 2011).

THOMAS Elli, SERWICKA Illona and sWINNEY Paul, Urban Demographics: Why people live where they do (London, Centre for Cities, 2015).

WATt Paul and MINTON Anna, “London's Housing Crisis and its Activism”, City 20:2 (2016), pp.

204-221.

WILCOX Steve and PERRY John, UK Housing Review, Briefing Paper (York, CHP, 2013).

WILSON David and GAME Chris, Local Government in the UK (Basingstoke, Palgrave, 2006).

\section{NOTES}

1. David Richie, Chief Executive of Bovis building firm, 2012 in Danny Dorling, All that is Solid (London, Penguin, 2015), p. 11.

2. William Field, Regional Dynamics: The Basis of Electoral Support in Britain (London, Franck Cass Publishers, 1997), p. 3.

3. Peter Scott, Triumph of the South: A Regional Economic History of Early Twentieth Century Britain (Aldershot, Ashgate, 2007), p. 3.

4. See Peter Malpass and Alan Murie, Housing Policy and Practice (Basingstoke, Routledge, 1999).

5. See Tony O'Sullivan and Kenneth Gibb, Housing Economics and Public Policy (Oxford, Blackwell, 2003).

6. See Glen Bramley, "The Sudden Rediscovery of Housing Supply as a Key Policy Challenge", Housing Studies 22:2 (2007), pp. 221-241.

7. Paul Balchin, Housing Policy: an Introduction (London, Routledge, 1995), p. 88-89.

8. David Mullins and Alan Murie, Housing Policy in the UK (Basingstoke, Palgrave, 2006).

9. With the exception of Alan Holmans, see Alan Holmans, Past and Current trends in House Prices and Incomes and Access to Home Ownership (Cambridge, Cambridge University Press, 2001). 
10. Some divide their statistics between London, 'wider South of England' and 'the Midlands and the North', see SAVILLS RESEARCH, Spotlight: Prime Residential Markets beyond London, London, Savills, 2015, retrieved on 2 April 2018, from http://www.savills.co.uk/research_articles/ 186866/187207-0. Others focus on the very divide: see NATIONWIDE, Price Index Press Release, March 2018, https://www.nationwide.co.uk/-/media/MainSite/documents/about/house-price-index/ 2018/Mar_Q1_2018.pdf.

11. Justine Piddington, Helen Garrett and Tad Nowak, Housing in the UK: National Comparisons in Typology, Condition and Costs of Poor Housing (Watford, IHS BRE Press, 2013), pp. 1-2.

12. DEPARTMENT OF THE ENVIRONMENT, Housing Policy: A Consultative Document (London, The Stationery Office, 1977), p. 12.

13. DOE, Our Future Homes: Opportunities, Choice, Responsibility (London, HMSO, 1995), p. 50.

14. ODPM, Your Region, Your Choice (London, HMSO, 2002).

15. DETR, Quality and Choice: A Decent Homes for All (London, DETR, 2000), p. 49; p. 71.

16. ODPM, Sustainable Communities: Building the Future (London, ODPM, 2003).

17. Peter Lee, "Competitiveness and Social Exclusion”, p. 195, in Peter Malpass and Rob Rowlands (eds), Housing, Markets and Policy (Abingdon, Routledge, 2010), pp. 184-202.

18. ODPM, Making it Happen: The Northern Way (London, ODPM, 2004).

19. DCLG, Homes for the Future: More Affordable, More Sustainable (London, DCLG, 2007), p. 17.

20. DCLG, Fixing our Broken Housing Market, Cm 9352 (London, DCLG, 2017), p. 19; p. 22.

21. Peter Lee, op. cit., p. 184.

22. Peter Malpass and Rob Rowlands, Housing, Markets and Policy (Abingdon, Routledge, 2010).

23. DOE, Planning Policy Guidance 12: Development Plans and Regional Planning Guidance, (London, HMSO, 1992), p. 3.

24. David Wilson and Chris Game, Local Government in the UK (Basingstoke, Palgrave, 2006), p. 182.

25. DETR, The Future of Regional Planning Guidance: Consultation Paper (London, The Stationery Office, 1998).

26. Glen Bramley, "The Sudden Rediscovery of Housing Supply as a Key Policy Challenge", Housing Studies 22: 2 (2006), pp. 221-241.

27. DCLG, Strategic Housing Market Assessment, Practice Guidance, Planning, London: DCLG, 2007, p. 7.

28. Glen Bramley, "Meeting Demand" in Peter Malpass and Rob Rowlands, op. cit., p. 170.

29. ODPM, Competitive European Cities: where do the Core Cities Stand? (London, ODPM, 2004); Kate Barker, Delivering Stability: Securing our Future Housing needs, Final Report (London, HM Treasury, 2004).

30. Peter Lee, op. cit., p. 184.

31. DCLG, Identifying Sub-regional Housing Market Areas (London, DCLG, 2007).

32. DCLG, Taking Forward the Review of Sub-national Economic Development and Regeneration (London, DCLG, 2007), p. 8.

33. DCLG, National Planning Policy Framework, (London, DCLG, 2012), § 159.

34. DCLG, Devolution: A Mayor for Greater Manchester (London, DCLG, 2017).

35. DCLG, Identifying Sub-regional Housing Market Areas, op. cit., p. 6.

36. Official statistics are presented by Middle Layer Super Output Areas, of which there are 7,201 in England and Wales.

37. Office for National Statistics, House Price Statistics for small areas: year ending December 1995 to year ending March 2016 (London, ONS, 2016), p. 7.

38. Justine Piddington et al., op. cit., p. 7.

39. THE POVERTY SITE, Poverty indicators: Non-decent homes, by region, retrieved from the Poverty Site on September $13^{\text {th }} 2016$, on www.poverty.org.uk/78/index.shtml 
40. The Decent Homes standard was introduced by the government in 2001 as a minimum standard for social landlords. A decent home is a home that meets the current statutory minimum standard for housing: it is in a reasonable state of repair, has reasonably modern facilities, provides a degree of thermal comfort. All social homes were to be refurbished by 2010 . By $2014,0.9 \%$ of the social stock did not meet the standard.

41. New kitchens and bathrooms were installed, buildings were insulated and windows changed.

42. Justine Piddington et al., op.cit.

43. Ibid.

44. Office for National Statistics, Table 109, Dwelling Stock by Tenure and Region from 1991, 2014, retrieved from www.gov.uk/government/statistical-data-sets/live-tables-on-dwelling-stockincluding-vacants

45. Justine Piddington et al., op.cit., p. 34.

46. Russell Lynch, "North-South divide in house prices is highest ever", The Independent, 30/12/2015, retrieved from http://www.independent.co.uk/news/business/north-south-dividein-house-prices-is-highest-ever-a6791326.html

47. Brian Miligan, "North South House Price Divide Hits Record High", BBCNews, 1 April 2016, retrieved from www.bbc.com/news/business-35941503

48. Office for National Statistics, Trends in the United Kingdom Housing Market (London, ONS, 2014), p. 16.

49. Office for National Statistics, Towns and Cities Analysis, England and Wales (London, ONS, March 2016), pp. 6-7.

50. Ibid., p. 4-5.

51. Ibid., p. 7.

52. Yolande Barnes, "Population Change:-the Market Impacts", in R. Bate, R. Best and A. Holmans (eds), On the Move: The Housing Consequences of Migration (York, Joseph Rowntree Foundation, 2000), p. 35.

53. Steve Wilcox and John Perry, UK Housing Review, Briefing Paper (York, CHP, 2013), p. 12.

54. HALIFAX, London thrives-widening the divide between the capital and the rest of the country, press release, 15/01/2015. Retrieved from https://static.halifax.co.uk/assets/pdf/mortgages/pdf/ London-thrives-widening-the-divide-between-the-capital-and-the-rest-of-the-country-15thJanuary-2015-Housing-Release.pdf.

55. Mayor of London, Homes for London, the Mayor's Housing Strategy (London, GLA, 2014), p. 16.

56. Although the definition of affordability is open to controversy, it is often accepted that unaffordability starts when a household spends more than $30 \%$ of their income on housing.

57. Mayor of London, op.cit.

58. The Economist, Living in London: the grip tightens (30 ${ }^{\text {th }}$ April 2016).

59. ONS, Housing Affordability in England and Wales: 1997 to 2016 (London, ONS, 2017), p. 6.

60. Office for National Statistics, Trends in the UK Housing Market, op.cit.

61. Office for National Statistics, UK House Prices Index: September 2017 (London, ONS, 2017), p. 7.

62. DCLG, English Housing Survey, Headline Report 2014-15 (London, ONS, 2016), p. 8.

63. Ibid., p. 2.

64. Resolution Foundation, Home Ownership struggle hits Coronation Street, 2 August 2016, http:// www.resolutionfoundation.org/media/press-releases/home-ownership-struggle-hitscoronation-street

65. Paul Watt and Anna Minton, "London's Housing Crisis and its Activism", City 20:2 (2016), p. 205.

66. Office for National Statistics, Overview of the UK population (London, ONS, 2016), p. 13.

67. HALIFAX, Press Release, op.cit. 
68. Mayor of London, Equal Life Chances for All (London, GLA, 2014), pp. 29-31.

69. Office for National Statistics, Towns and Cities Analysis, England and Wales, op. cit., p. 4.

70. Ibid., p. 5.

71. Tom Lloyd, "Figures reveal scale of regional house price divide", Inside Housing, 2 January 2016.

72. Resolution Foundation, op. cit.

73. HOMETRACK, UK Cities House Price Index released (July 2016),

retrieved https://www.hometrack.com/uk/insight/uk-cities-house-price-index/july-2016-citiesindex

74. The Economist, "Housing in British Cities: Little Londons", $24^{\text {th }}$ September 2016.

75. Elli Thomas, Ilona Serwicka and Paul Swinney, Urban Demographics: Why people live where they do (London, Centre for Cities, 2015), p. 17.

76. Brian Lund, Housing Politics in the UK: Power, Planning and Protest (Bristol, Policy Press, 2016), p. 242.

77. Ibid., p. 247.

78. Ibid.

79. Ibid.

80. Ibid.

81. Ibid. pp. 243-44.

82. Distinction between priority and non-priority need was abolished and settled accommodation guaranteed, Ibid., p. 245.

83. Ibid., p. 250.

84. Ibid., p. 251.

85. Ibid., p. 255.

86. Scottish Government, Homes Fit for the $21^{\text {st }}$ Century, The Scottish Government Strategy and Action Plan for Housing in the Next Decade, 2011-2020 (Edinburgh, Scottish Government, 2011), p. 8.

87. See http://gov.wales/newsroom/housing-and-regeneration/2018/180313-first-residentsthrow-open-their-doors-in-42m-land-for-housing-scheme/?lang=en, accessed 2 April 2018.

88. John Hills et al., An Anatomy of Economic Inequality in the UK: Report of the National Equality Panel (London, Government Equalities Office, 2010), p. 247.

89. Ibid., p. 258.

90. ONS, UK House Prices Index, op. cit.

91. Larry Elliott, "House Prices to fall in London and South East, say Surveyors", The Guardian, 20 December 2017.

92. Dawn Foster, "More families are renting and fewer people expect to ever own a home", The Guardian, 25 February 2016, retrieved from https://www.theguardian.com/housing-network/ 2016/feb/25/families-renting-2016-english-housing-survey

\section{RÉSUMÉS}

Héritages de la révolution industrielle, les différences en matière de logement et d'urbanisme entre le Nord et le Sud du Royaume-Uni sont fréquemment invoquées pour donner corps au fossé Nord-Sud. Cependant, une analyse des marchés immobiliers et des conditions de logement contribue à nuancer, voire infirmer ce concept. Cet article examinera donc le fossé Nord-Sud au 
prisme du logement, non pas dans une perspective de politiques publiques mais d'analyse des marchés immobiliers et des conditions de vie. Il commencera par se pencher sur le discours des pouvoirs publics dans le domaine du logement, avant d'expliquer l'importance croissante donnée au niveau infrarégional. Les différences de logement seront étudiées sur la base de quatre indicateurs (aspect physique, état, statut d'occupation, prix). Nous montrerons qu'il est nécessaire de dépasser la grille de lecture Nord-Sud afin de mesurer les inégalités de logement contemporaines. Enfin, la question de la divergence des politiques de logement dans un contexte post-dévolution sera posée.

As a legacy of the industrial revolution, housing differences in the UK are frequently referred to in order to exemplify the so-called North-South divide. However, a closer analysis at UK housing markets shows that it is necessary to qualify if not debunk that concept. This article will examine the North-South divide not so much from a public policy perspective as from a housing markets and housing conditions perspective. Firstly, I shall briefly analyse the official discourse with regard to a North-South divide in housing. Next, I shall examine the issue of the rescaling of housing and the growing importance given to the sub-regional level in England. Secondly, I shall examine the relevance of the North-South divide in housing in the UK on the basis of four indicators (physical aspect, state of repair, tenure, prices). Thirdly, I shall raise the question of the emergence of new and more relevant housing divides in England. Finally, I shall explore the question of housing policy divergence in a post-devolution UK.

\section{INDEX}

Mots-clés : Logement, fossé Nord-Sud, marchés immobiliers, Royaume-Uni post-dévolution Keywords : Housing, North-South divide, housing markets, post-devolution UK

\section{AUTEUR \\ DAVID FÉE}

CREW (EA 4399), Université Sorbonne Nouvelle 